\title{
Large leakage incident in a Norwegian concrete faced rockfill dam due to ice build up
}

Robin Peter Harold Wood Meng, Ceng, MICE

Vice President, Civil Structures, Statkraft Energi AS, Oslo, Norway (corresponding author: robin.wood@statkraft.com)

Trine Indergård Carr MSC

Vassdrag Teknisk Ansvarlig, Statkraft Energi AS, Oslo, Norway
Tiemen Johannes Gordijn MSc

Engineering Geologist, Multiconsult Norge AS, Oslo, Norway

Aursjø dam is a concrete faced rockfill dam (CFRD) in central Norway built between 1950 and 1958 and owned by Statkraft. The dam was originally constructed with an upstream face consisting of wooden planks, which acted as the impermeable element of the dam. The dam underwent a large rehabilitation between 2005 and 2006, when the wooden planks were replaced with a reinforced-concrete slab. In 2017 a large leakage event occurred at the dam and at its peak was estimated to be up to $600 \mathrm{l} / \mathrm{s}$. This paper covers the incident itself including the emergency response, the investigation into the cause of the high leakage, the potential effect on dam safety, and finally the recommended measures implemented at the dam. During the detailed investigation the cause of the leakage was identified as the release of water after an ice dam within the dam body burst. Ice build-up and subsequent rapid release of water is not an unusual occurrence at rockfill dams in Norway and there are examples where the same phenomena has occurred at other dams.

\section{Background and dam history}

Aursjø reservoir is located $30 \mathrm{~km}$ south of Sunndalsøra in central Norway, with a reservoir volume of $903000 \mathrm{~m}^{3}$ and a top water level of $856 \mathrm{~m}$ above sea level (asl).

Aursjø dam is a $40 \mathrm{~m}$ high concrete faced rockfill dam (CFRD) with a crest length of approximately $900 \mathrm{~m}$. The dam was originally built with quarried rockfill and rockfill from the tunnel excavations, with concrete slab and timber as the upstream seal. The dam was built between 1950 and 1958 with the last large rehabilitation occurring between 2005 and 2006. The dam is placed in consequence class 3 , which is the second highest consequence of dam in Norway.

A short history of the main events in the dam history is given below.

- During the 1950-1958 construction period there was damage to the dam crest during a storm in 1957. The water level was at 854.90 masl and the wave wall was not built. The wave wall was subsequently built to 857.70 in 1958 and the dam top was raised by $1 \mathrm{~m}$ to 857.5 masl.

- In 1964 a storm caused major damages to the dam top. Water level restrictions was set at 854.5 masl from 1964 to 1967 .

- In 1967 the wave wall was raised to 858.55 masl. Four leakage houses were established with a subsequent leakage measurement rate of $150 \mathrm{l} / \mathrm{s}$ at the highest regulated water level.
- Restriction of the highest regulated water level of 1-2 m from 1977 to 1983 .

- In 1984 the dam was raised to 860 masl due to the current emergency preparedness requirements. The downstream side was adjusted to a slope of $1 \mathrm{~V}: 1.4 \mathrm{H}$ with a total of $168800 \mathrm{~m}^{3}$ stone added.

- By 1990 the leakage had increased up to $350 \mathrm{l} / \mathrm{s}$.

- In 1993 the top $10 \mathrm{~m}$ of the plank deck was replaced with sprayed concrete which reduced the leakage to $180 \mathrm{l} / \mathrm{s}$.

- In 2005-2006:

- The wooden planks were removed and replaced with a reinforced-concrete slab.

- Grouting in the dam foundation.

- Raising of the dam crest.

- New wave wall constructed.

- New leakage measurement housing with remote reading.

- New bottom outlet and plugging the original bottom outlet.

- Automatic water level measurement.

\section{The incident}

On 19 September 2017 at the operations centre, an abnormally high leakage was registered at leakage house 3 , with the leakage volume increasing rapidly. Since the leakage - in addition to flowing through the leak measuring house - also ran around both sides of the house, there was no accurate measurement of the leakage. However, it is estimated that the peak was around $600 \mathrm{l} / \mathrm{s}$, with the leakage reducing to 
approximately $1 \mathrm{l} / \mathrm{s}$ by the evening of the following day. The total volume over the $24 \mathrm{~h}$ incident period was approximately $5000 \mathrm{~m}^{3}$. The analysis presented in this paper is based on Multiconsult Norge AS (2018) report.

During the incident the temperature of the leakage water and that of the reservoir was measured using a hand-held

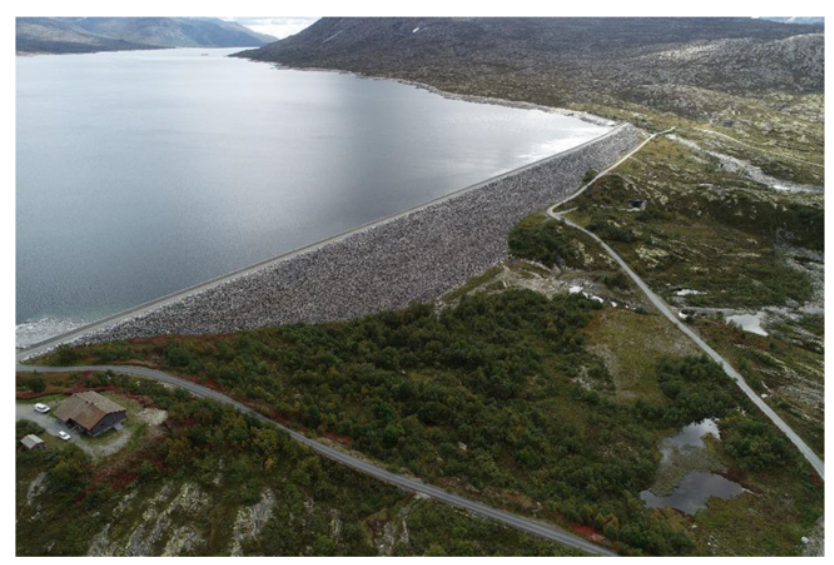

Figure 1. Aerial view of Aursjø dam thermometer. The measurement showed that the water temperature of the leakage water was approximately $0^{\circ} \mathrm{C}$, while the surface temperature of the reservoir was approximately $8^{\circ}$. On the basis of this information it was correctly concluded (albeit not conclusive at the time) that the leakage water was not coming directly from the reservoir and therefore no evacuation downstream was carried out (Figures 1-5).

\section{Review of the documentation}

3.1 Leakage data from metering housing 3 (M3) A review of all leakage data from 2007 when the leakage measurement houses were installed has been carried with special attention given to leakage measurement house 3 .

A possible relationship between leakage and precipitation/snow melt has been considered. Figure 6 shows this relationship during 2008-2017 with the green dotted line showing the theoretical relationship. In the years preceeding the incident (2013-2015) there was less leakage than expected based on rain and snow melt (the years are below the dotted line). This may indicate that leakage water accumulated over several years/seasons (Figure 7).

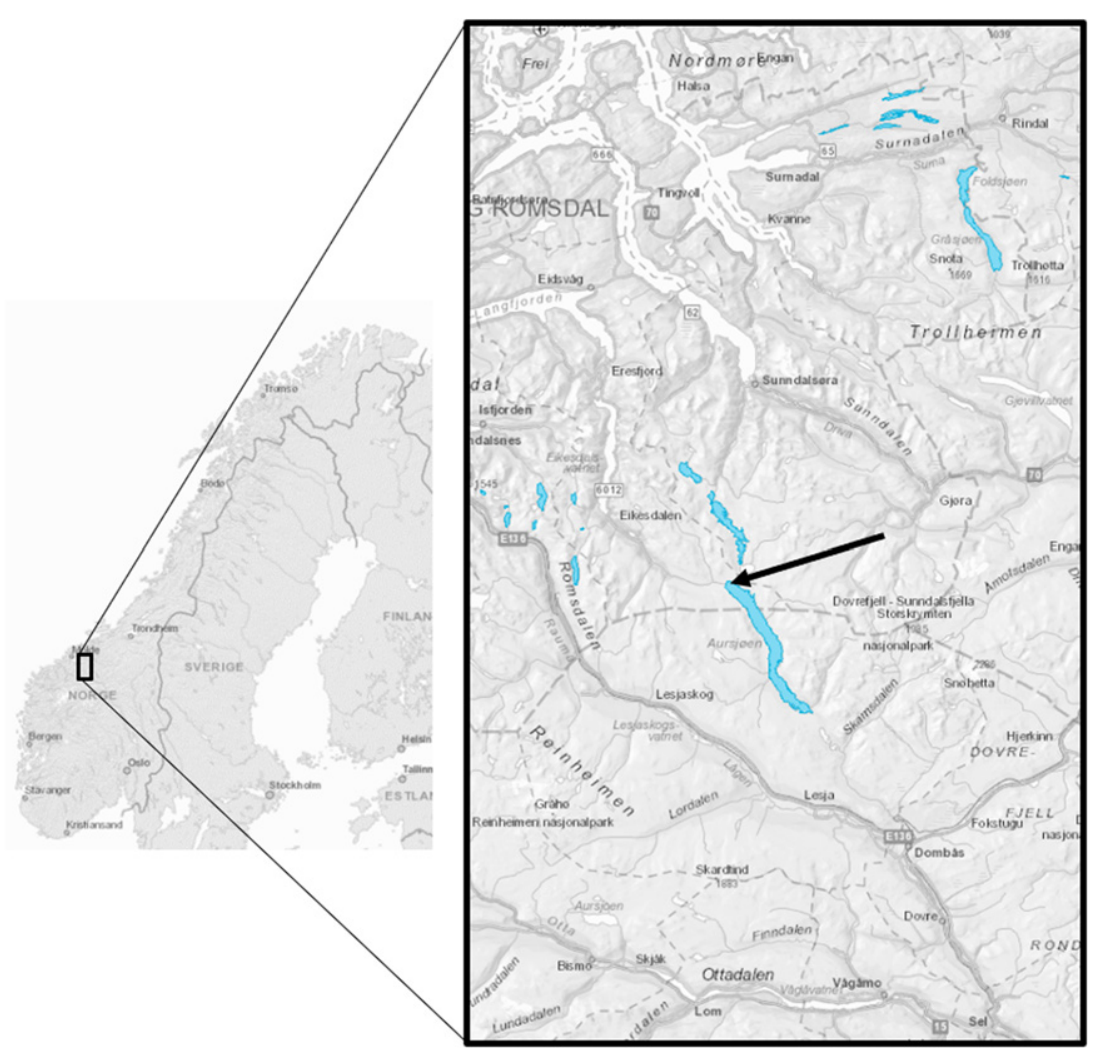

Figure 2. Location of Aursjø dam 


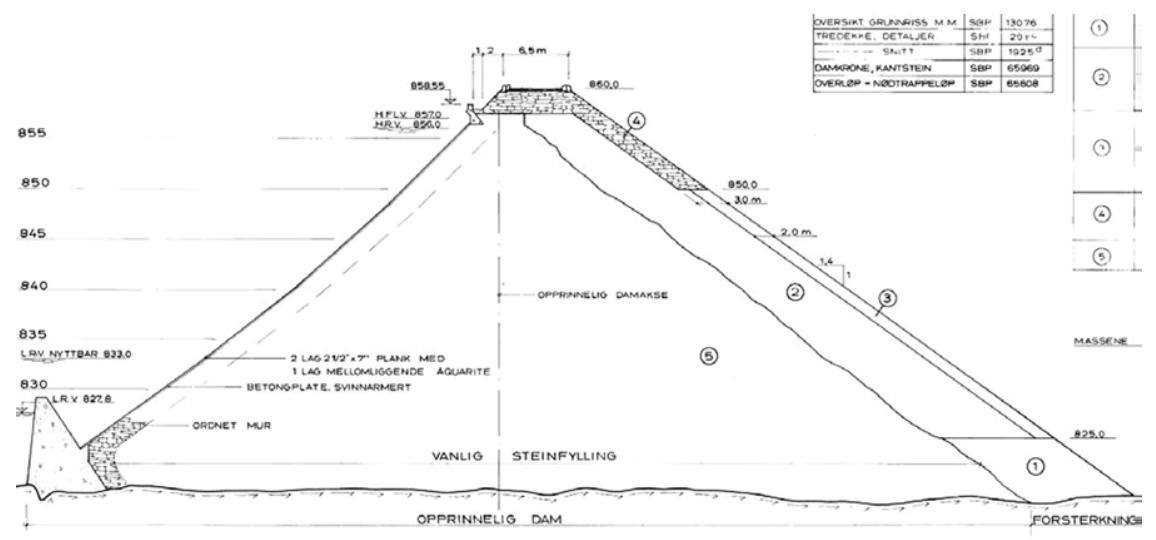

Figure 3. Section of the dam (after raising in 1984)

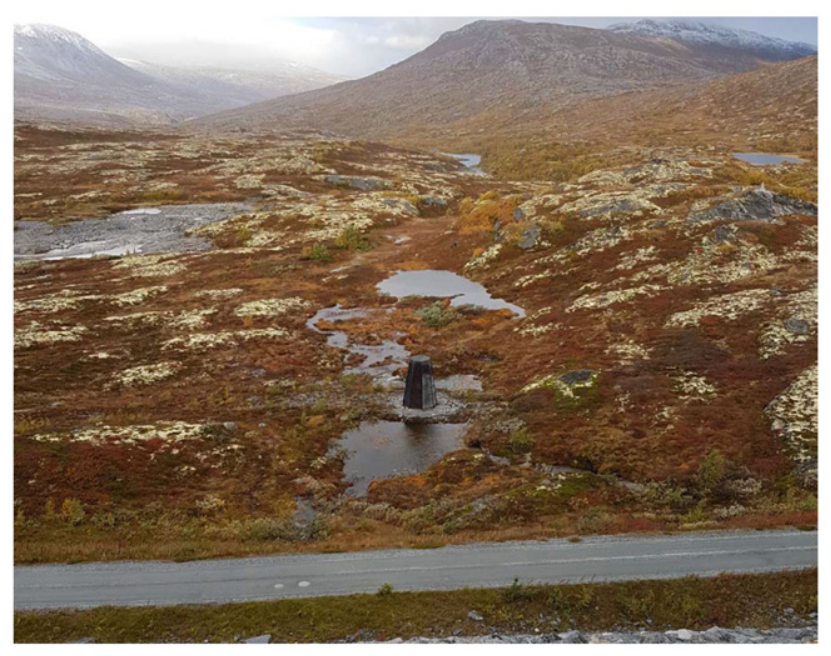

Figure 4. Leakage water surrounding the measurement house during the incident on 19 September 2017

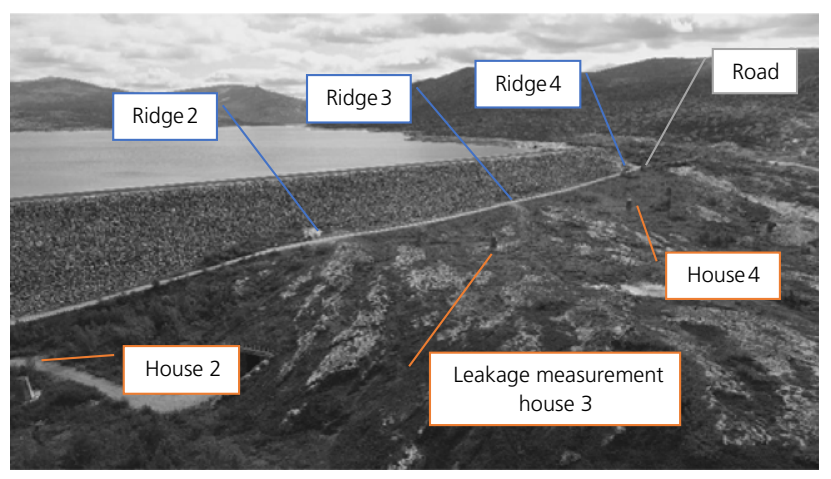

Figure 5. Overview of the left side of the dam

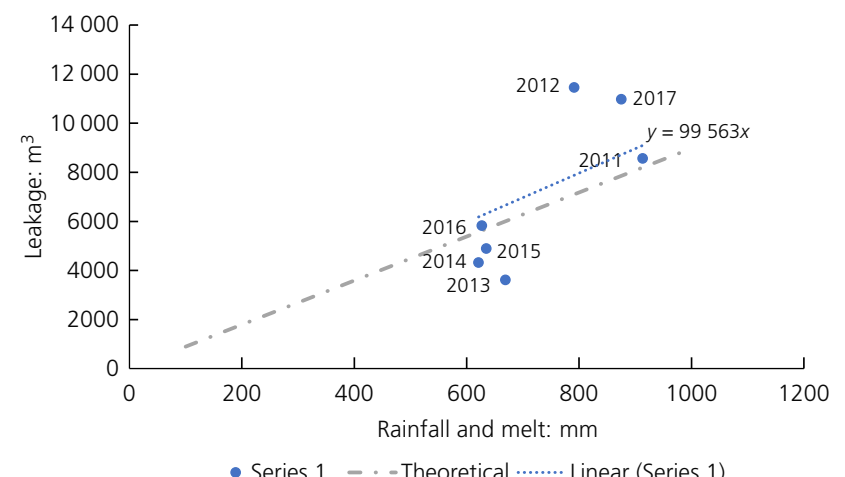

Figure 6. Curve showing leakage against rainfall and snowmelt for measurement house 3

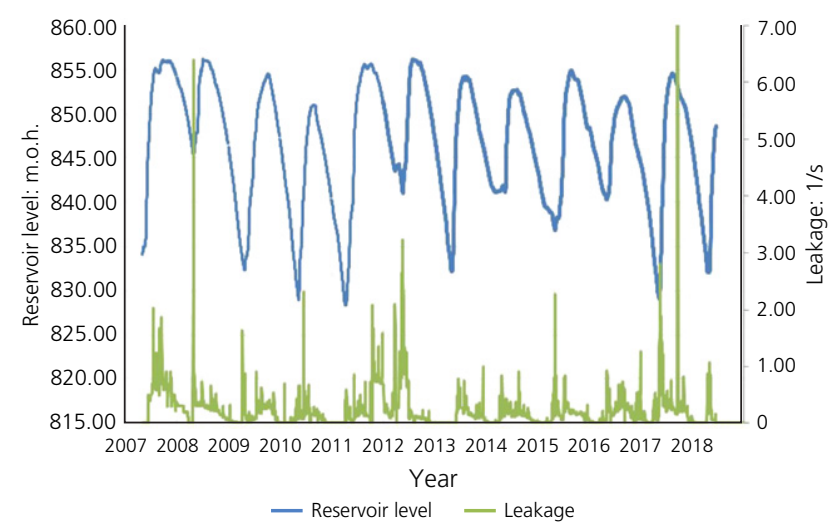

Figure 7. Curve showing leakage from house 3 and reservoir level 
A graphical representation of the leakage from measuring house 3 is made in connection with the water level in the reservoir. The graph shows data during 2007-2018. Most of the high leakage values are related to snowmelt and rainfall, especially the high values around May.

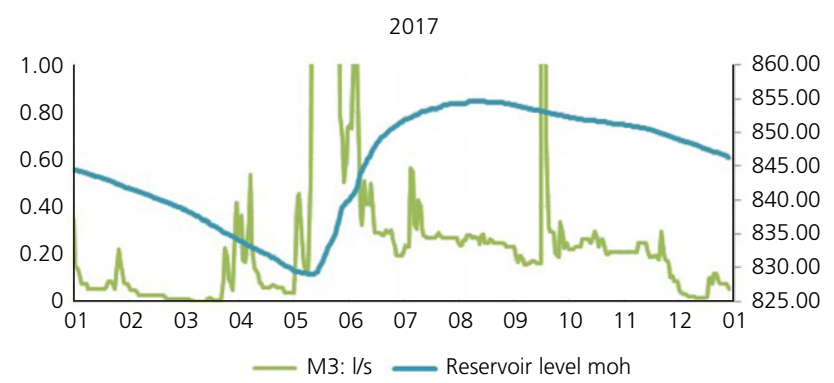

Figure 8. Curve showing leakage from measuring housing 3 and reservoir level for 2017

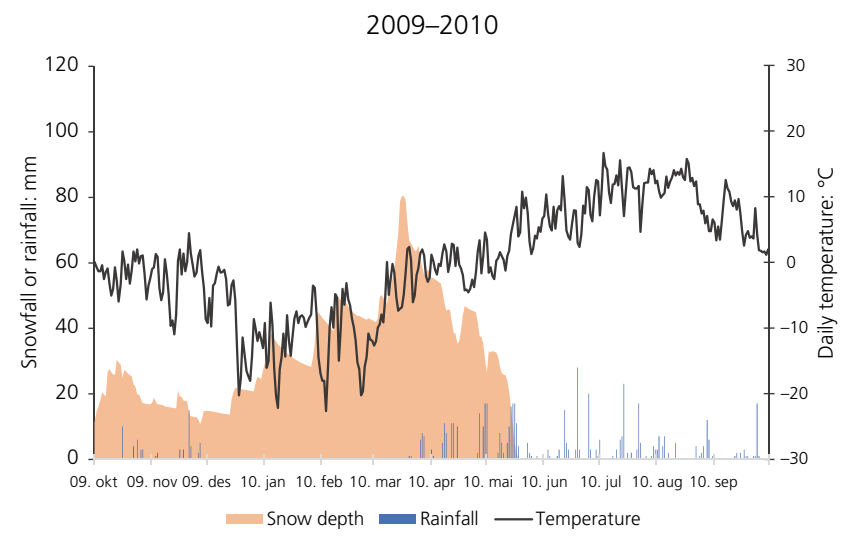

(a)

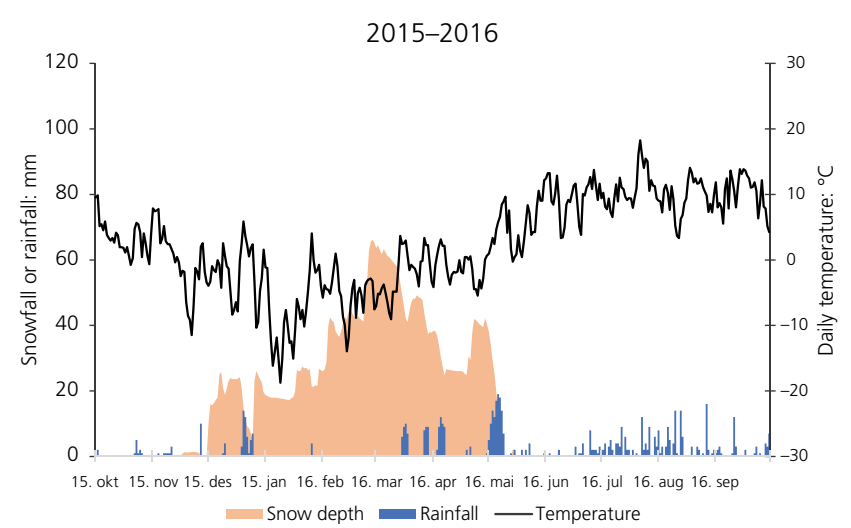

(c)
Figure 8 shows leakage at measuring house 3 and reservoir level for 2017. The graphical presentation shows a correlation between leakage and reservoir level. In other words, the leakage increases as the water level rises (disregard the peaks caused by rain and snow melt).

In the time around the incident this trend is also seen with the correlation between water level and leakage. The actual incident however, shows no relation to the water level in the reservoir (Figures 9 and 10).

\subsection{Climatic conditions}

A review of the precipitation, temperature and snow depth data over recent years, in particular 2009-2011 and 2015-2017, has been carried out to see if there is any connection between the three parameters and high leakage observed.

The reason for taking a closer look at the data for 2009-2011 is that the reservoir level in winter of 2010 and 2011 was similar to the level for winter 2017.

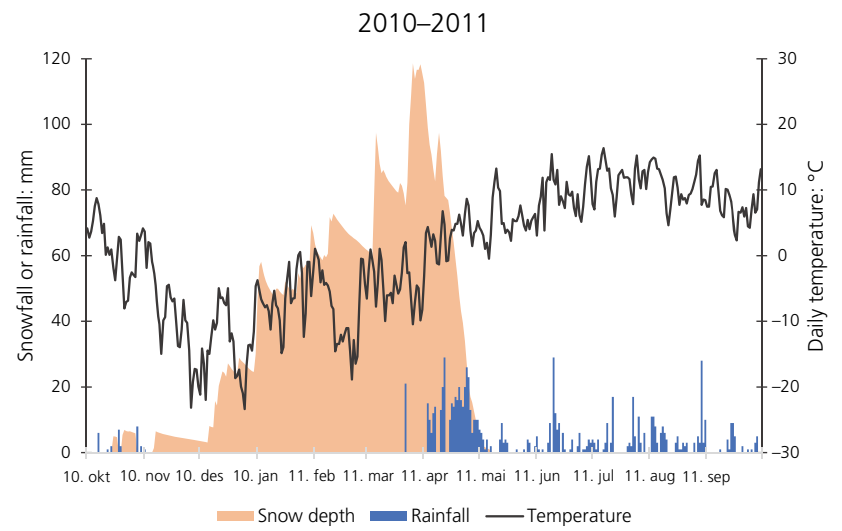

(b)

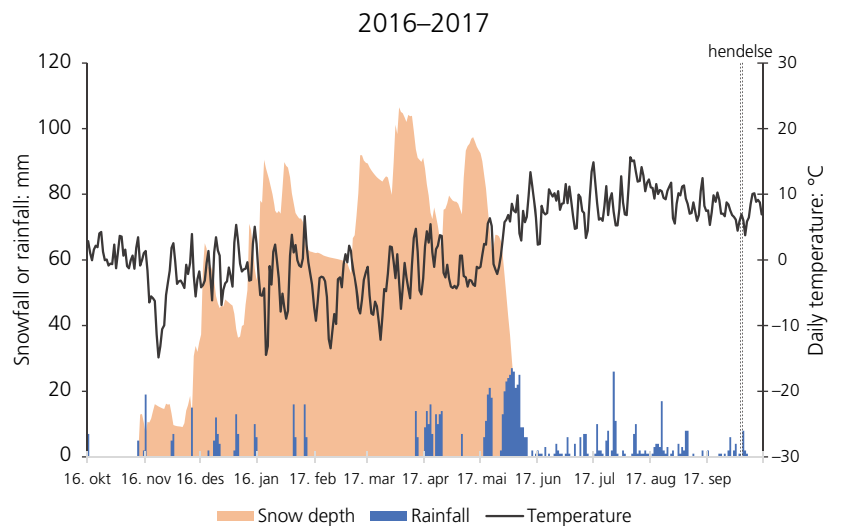

(d)

Figure 9. Graphical overview of rainfall, temperature and snow depth for the Aursjø dam 


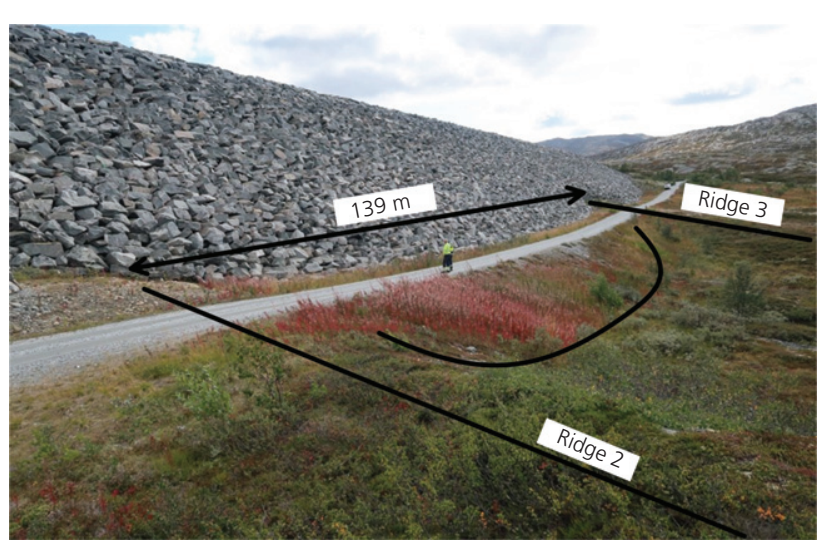

Figure 10. Dam toe between ridge 2 and 3, upstream of leakage measurement house 3

The data show that winter 2016/2017 and partly also 2015/2016 had a higher temperature than previous years, including 2010 and 2011.

\section{Possible causes of the leak outbreak}

Below is an assessment of the possible causes of the incident.

\subsection{Ice collection in downstream dam slope/road filling}

Along parts of the downstream toe of the dam there is a road which is constructed of gravel and potentially fine-grained frost-susceptible materials. By reviewing the topography an estimate has been made for how much water can be retained behind the road filling within the dam. A three-dimensional model has been created based on drone scanning during inspection. Based on this along with topographic map for the dam foundation and dam volume/cross-section, it is calculated how much water could be stored behind the road filling between ridges 2 and 3. The result shows that there is room for $8590 \mathrm{~m}^{3}$ of water behind the road filling in this area if one expects a porosity of $20 \%$ for the rockfill. It is estimated that the total leakage volume on 19 September 2017 was $5000 \mathrm{~m}^{3}$, which is well within the calculated volume.

A possible cause is that the downstream section of the dam body/road embankment freezes through the winter and dams up water within the dam, and when this ice dam bursts the water is released rapidly.

- Temperature measurements support this scenario as the leakage water was a good deal colder than the water in the reservoir.

- There is sufficient space in the dam to store the amount of water released.

- This scenario explains why the leakage increased and decreased rapidly.
- If the masses in the road embankment between ridge two and three are susceptible to freezing, it explains why the major leak occurred in this location.

- The winter before had been warmer than normal, in addition there had been great snow depth which may have impaired ice build-up, causing the ice dam to be weaker.

\subsection{Ice collection on the upstream side}

Ice collection on the upstream side below the concrete slab.

- There is not enough space in this area to contain $5000 \mathrm{~m}^{3}$ of water.

\subsection{Cracks in upstream concrete deck}

Cracks/joint openings or other upstream concrete deck leading to leakage from the reservoir.

- This is unlikely because the leak does not correlate with the fluctuation of the reservoir level; the water level was decreasing.

- The maximum leakage value of $600 \mathrm{l} / \mathrm{s}$ is very high, and it is unlikely that this rate of flow could pass through a crack in the concrete slab.

- No large cracks were observed in the concrete slab during a remote operated vehicle (ROV) inspection in 2018.

- The temperature of the leakage water $\left(0^{\circ}\right)$ was colder than the $8^{\circ}$ surface water temperature. The water is likely to be no lower than $4^{\circ}$ at the base of the reservoir (due to water being heaviest at $4^{\circ}$ ). This means that the water is unlikely to come directly from the reservoir.

\subsection{Leakage through foundation}

Leakage through the rock foundation, such as a split in the foundation, by hydraulic splitting, or through a 'temporary' erosion.

- During the reconstruction in 2005-2006, the leakage increased as the water level rose and approached highest regulated water level. In September 2017, the water level was on its way down. It is normal for such a leak to increase with increased water pressure.

- The temperature of the leakage water $\left(0^{\circ}\right)$ was colder than $4^{\circ}$. It is therefore not likely that the water comes directly from the reservoir.

\section{Conclusion}

The documentation review supports the assessment that the outbreak of the leak was due to an ice accumulation that burst in the dam body between ridges 2 and 3 in September 2017.

It is considered that the ice collection in the road filling has been built up over several years and the ice collection was in 2017 weaker due to the two previous warmer years. The most 
important indicator is the water temperatures that show that the water did not come directly from the reservoir and the volume of water.

The reason for the outbreak of leakage to happen at the site it did is in all likelihood the topography between the two ridges and the road filling along the downstream toe. The materials in the road filling are finer than a normal rockfill, and is thus more susceptible to frost and ice (especially if there is a supply of leakage water).

One can assume that an ice collection is already on the way to recurring, and that a similar incident can happen again. A similar incident does not pose a danger to the safety of the dam as the dam will remain stable due to the shear strength of the rockfill, and there is no risk from internal erosion of the rockfill as it will remain stable under a similar leakage flow. Temperature measurements of both the leakage water and several levels in the reservoir are therefore crucial to determine the source of the water so it can be quickly concluded if a large leakage is due to ice collection within the dam body and not directly from the reservoir.

\section{Measures taken}

Statkraft has implemented a number of measures following the outbreak of the leak. The measures have been reported to the Norwegian Water Resources and Energy Directorate (NVE) who are the regulatory authority of the Norwegian dam safety regulations (Norwegian Ministry of Petroleum and Energy, 2009):

- Water temperature measurement systems in the four leakage measurement houses have been installed and connected to a Scada system. In addition, wind and air temperature gauges were mounted in a mast by the dam.

- Two web cameras are mounted. One on leakage measuring housing 3 showing the area where the leak outbreak exited the dam, the other is mounted on a mast that shows the whole reservoir and the surrounding area.

\section{Additional recommended measures}

In addition to measures already implemented, the following has been recommended:

- Installation of a temperature gauge at the top and bottom of the reservoir upstream of measurement house 3.

- Perform a test excavation in the road filling upstream of measurement house 3 to observe if the road is frozen. This should be carried out in the spring after the snowmelt.

- Perform a grain grading analysis of the road embankment material.

- Installation of a pipe through the road embankment to drain water from behind the embankment.

- After the above measures have been implemented a review should be carried out of the findings and an assessment carried out to determine if piezometers need to be installed in the dam body upstream of measuring houses 2 and 3 to monitor the water level within the dam.

\section{REFERENCES}

Multiconsult Norge AS (2018) Aursjo dam Lekkasjeutbrudd 19. September 2017 - 10204079-RIVass-RAP-02. Multiconsult Norge AS, Oslo, Norway.

Norwegian Ministry of Petroleum and Energy (2009) Forskrift om Sikkerhet ved Vassdragsanlegg (Damsikkerhetsforskriften). Norwegian Dam Safety Regulations, Norwegian Ministry of Petroleum and Energy, Oslo, Norway.

\section{How can you contribute?}

To discuss this paper, please email up to 500 words to the editor at editor@britishdams.org. Your contribution will be forwarded to the author(s) for a reply and, if considered appropriate by the editorial board, it will be published as discussion in a future issue of the journal. 